\title{
TOWARDS A RADIOCARBON CALIBRATION FOR OXYGEN ISOTOPE STAGE 3 USING NEW ZEALAND KAURI (AGATHIS AUSTRALIS)
}

\author{
Chris S M Turney ${ }^{1} \cdot \mathrm{L}_{\text {Keith Fifield }}^{2} \bullet$ Jonathan G Palmer $^{3} \bullet$ Alan G Hogg $^{4} \bullet$ Mike G L Baillie $^{5} \bullet$ \\ Rex Galbraith ${ }^{6} \cdot \mathrm{John}_{\mathrm{Ogden}}{ }^{7}$. Andrew Lorrey ${ }^{7} \bullet$ Stephen G Tims ${ }^{2}$
}

\begin{abstract}
It is well known that radiocarbon years do not directly equate to calendar time. As a result, considerable effort has been devoted to generating a decadally resolved calibration curve for the Holocene and latter part of the last termination. A calibration curve that can be unambiguously attributed to changes in atmospheric ${ }^{14} \mathrm{C}$ content has not, however, been generated beyond $26 \mathrm{kyr}$ cal BP, despite the urgent need to rigorously test climatic, environmental, and archaeological models. Here, we discuss the potential of New Zealand kauri (Agathis australis) to define the structure of the ${ }^{14} \mathrm{C}$ calibration curve using annually resolved tree rings and thereby provide an absolute measure of atmospheric ${ }^{14} \mathrm{C}$. We report bidecadally sampled ${ }^{14} \mathrm{C}$ measurements obtained from a floating 1050 -yr chronology, demonstrating repeatable ${ }^{14} \mathrm{C}$ measurements near the present limits of the dating method. The results indicate that considerable scope exists for a high-resolution ${ }^{14} \mathrm{C}$ calibration curve back through OIS-3 using subfossil wood from this source.
\end{abstract}

\section{INTRODUCTION}

Highly precise and accurate calibration of radiocarbon ages is critical for developing late Pleistocene chronologies of paleoenvironmental change and archaeological research. Although considerable effort has been expended in developing continuous comparison curves encompassing the entire dating range of ${ }^{14} \mathrm{C}$ (e.g. Kitagawa and van der Plicht 1998, 2000; Voelker et al. 2000; Yokoyama et al. 2000; Beck et al. 2001; Hughen et al. 2004; van der Plicht et al. 2004; Fairbanks et al. 2005), an internationally accepted record spans only the last $26 \mathrm{kyr}$ cal BP (Reimer et al. 2004). Significant differences exist between the published records $>26 \mathrm{kyr}$ cal BP (van der Plicht et al. 2004; Turney et al. 2006). This relatively high degree of variability arises from uncertainties in the absolute dating of the calendar timescale and/or from uncertainty in the extent to which the radiocarbon measurements accurately represent atmospheric ${ }^{14} \mathrm{C}$ content. An accurate and precise ${ }^{14} \mathrm{C}$ calibration curve should be based on an absolutely dated record that has carbon incorporated directly from the atmosphere at the time of formation. Tree rings have proven to be an excellent resource for this purpose.

At present, by utilizing central European trees, the earliest part of the calibration curve based on dendrochronologically dated material extends back to $12.4 \mathrm{kyr}$ cal BP (i.e. into the Younger Dryas chronozone) (Friedrich et al. 2004). Although the calibration is currently being extended into the Lateglacial period using new finds of subfossil pine, it appears unlikely that this region will provide suitable trees beyond the last glacial maximum (LGM; about $18 \mathrm{kyr} \mathrm{BP}$ ). The extent and magnitude of the Northern Hemisphere ice sheets during the LGM effectively limited the number of sites where tree populations could be sustained and appear to have destroyed any significant burials of pre-

'GeoQuEST Research Centre, School of Earth and Environmental Sciences, University of Wollongong, Wollongong, NSW 2522, Australia. Corresponding author. Email: turney@uow.edu.au.

${ }^{2}$ Department of Nuclear Physics, Research School of Physical Sciences and Engineering, Australian National University, Canberra, ACT 0200, Australia.

${ }^{3}$ Gondwana Tree Ring Laboratory, P.O. Box 14, Little River, Banks Peninsula, Canterbury 8162, New Zealand.

${ }^{4}$ Radiocarbon Laboratory, University of Waikato, Private Bag, Hamilton, New Zealand.

${ }^{5}$ Department of Archaeology and Palaeoecology, School of Geography, Archaeology and Palaeoecology, Queen's University, Belfast, BT7 1NN, United Kingdom.

${ }^{6}$ Department of Statistical Science, University College London, Gower Street, London, WC1E 6BT, United Kingdom.

${ }^{7}$ School for Environmental \& Marine Sciences, Tamaki Campus, Auckland University, Private Bag 92019, Auckland, New Zealand. 
served wood material within the stratigraphic record. In locations away from the effects of ice, the conditions for wood preservation were typically not present. As a result, little material appears to have survived through to today.

In exceptional situations, the preservation of subfossil trees can occur within former glaciated environments. One example in the Southern Hemisphere is at Seno Reloncaví in northern Patagonia, Chile (Roig et al. 2001). Here, 28 Fitzroya cupressoides trees produced a 1229-yr floating chronology dated at $>50 \mathrm{kyr}$ BP, interpreted to be in the early part of oxygen isotope stage 3 (OIS-3; 60-25 kyr cal BP). The position and orientation of the stumps suggested that the trees were overwhelmed by a lahar and were thus preserved as the result of a catastrophic single event. This, and the serendipitous nature of their discovery (a result of a recent earthquake and subsequent marine erosion exposing the subfossil $F$. cupressoides stumps) imply that the prospects are slim for finding a series of similar sites in this area that would cover an extended time period.

A more exciting possibility for ${ }^{14} \mathrm{C}$ calibration beyond $26 \mathrm{kyr}$ cal BP is subfossil kauri (Agathis australis), buried in bogs scattered over a 300-km stretch of northern New Zealand (Cranwell 1939; Ogden et al. 1992; Palmer et al. 2006; Figure 1). Living tree cores from a network of sites have been collected (Buckley et al. 2000; Fowler et al. 2000) and this chronology was recently linked to late Holocene subfossil sites (Boswijk et al. 2006). At the same time, a collection of significantly older subfossil kauri has been obtained from 16 different locations, and several floating tree-ring chronologies are in varying stages of development. The remarkable state of preservation of "ancient" kauri, coupled with the renowned timber qualities of the species has meant it is a valuable resource. As a result, the wood is currently being "harvested" for commercial purposes (Figure 2). This has resulted in a rapid rate of extraction, and the resource is dwindling. Some of the buried trees are of enormous proportions, with diameters greater than $4 \mathrm{~m}$ and individual ages of more than $2000 \mathrm{yr}$ (Palmer et al. 2006). This wood and associated preserved material represent an immense store of information about past climate. The time span covered ( $>40 \mathrm{kyr}$ BP) and the potentially detailed climatic reconstructions possible from the long series of annual rings preserved in these trees (Buckley et al. 2000; Fowler 2000) means that this wood is a scientific resource of international significance.

Here, we report on the potential of kauri for high-precision calibration of the ${ }^{14} \mathrm{C}$ timescale beyond $26 \mathrm{kyr}$ cal BP. This work is part of a collaborative research program using both accelerator mass spectrometry (AMS) and high-sensitivity liquid scintillation counting (LSC). The LSC methodology and results are reported elsewhere (Hogg et al., these proceedings). The results described here are principally those obtained by AMS, although "rangefinder" LSC ages are included for completeness.

\section{METHODS}

\section{Sampling}

Samples of subfossil kauri have been obtained from across Northland, New Zealand (Figure 1). One of the sites reported in detail here, Trig Road (on the Aupouri Peninsula; Ogden et al. 1993), is typical of the depositional environments from which subfossil kauri are being extracted. Trig Road lies within an area of Pleistocene sands with scattered semi- and unconsolidated sands of Holocene age; the relatively low, undulating landscape is made up of scattered bogs containing preserved logs and litter material. A total of 10 partial and complete cross-sections from logs were collected from the Trig Road stack gathered by a sawmiller. This method of sampling is the mechanism by which we collect kauri material; a fully funded program to locate, extract, and systematically sample logs would be prohibitively expensive. We therefore work closely alongside the milling companies, mak- 


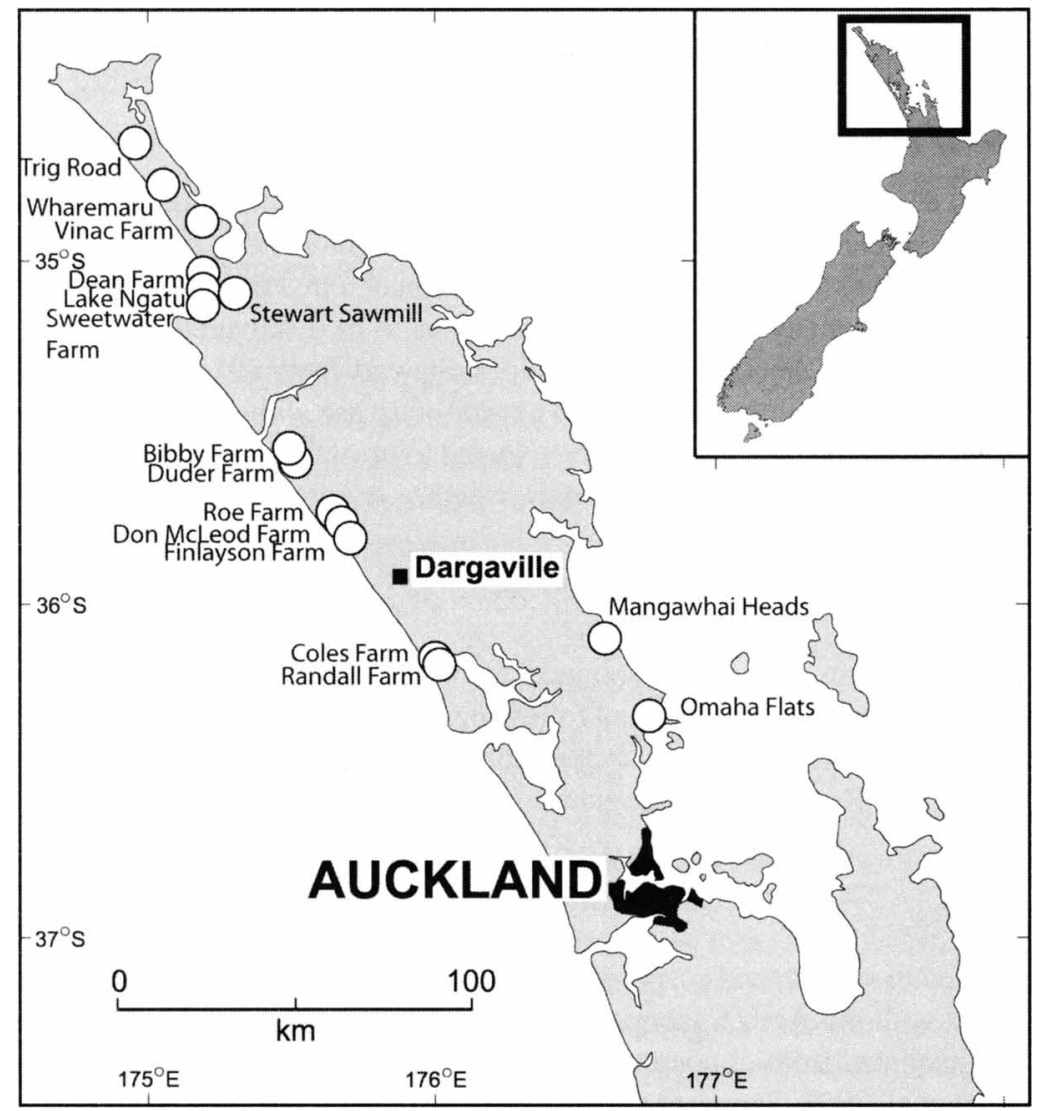

Figure 1 Location of ancient (oxygen isotope stage 3) kauri (Agathis australis) deposits reported in this study, Northland, New Zealand.

A.

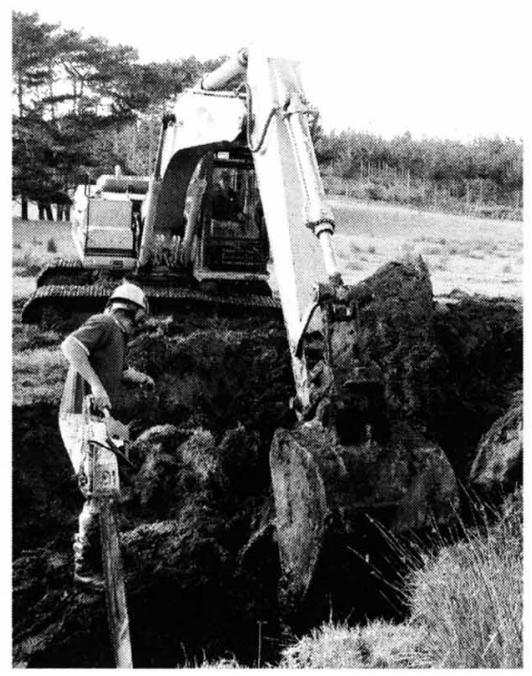

B.

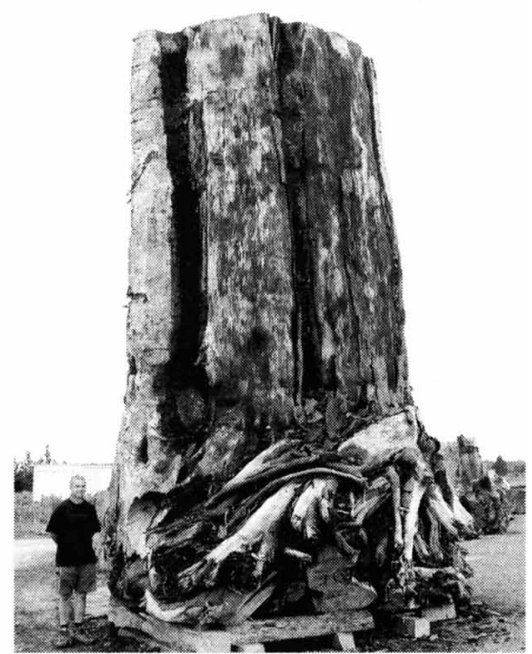

Figure 2 Extraction (A) and storage (B) of ancient kauri (Agathis australis) samples ( $\mathbf{J}$ Palmer pictured) prior to commercial processing (Northland, New Zealand). 
ing the project economically feasible. One consequence of this, however, is that we have no selection or choice of location for sampling. As logs are extracted, they are often stockpiled while waiting for transportation to local mills. It is at this point that we select suitable samples; these are then freighted to us for drying before being surfaced for dendrochronological analysis.

Typically, the logs are extracted from bogs on dairy farms where much of the original vegetation was cleared during the early 20th century. Many of the bogs have been partially drained and often fires have passed over the area. This has meant any portion of a tree that had been on the surface has disappeared. Despite this, many remarkable logs continue to be discovered; an excellent example is the Awanui "staircase" tree (Ancient Kauri Kingdom, Stewart Sawmill), which contains 1090 rings and is $3.8 \mathrm{~m}$ in diameter, sufficient in size to cut a spiral staircase within the main trunk. Some of the wood samples investigated in this project were selected to provide a reliable assessment of the total blank for the procedures used and to determine whether coherent geochronological information could be obtained on samples $>40 \mathrm{kyr}$ BP.

\section{Dendrochronological Analysis}

"Biscuits" or cross-sections have been obtained from numerous sites containing subfossil trees. Tree-ring samples are prepared and analyzed following well-documented dendrochronological techniques for ring-width measurement and cross-dating (e.g. Stokes and Smiley 1968; Fritts 1976; Baillie 1982). The Trig Road sample measured here was Specimen 9 described by Ogden et al. (1993).

\section{Radiocarbon Dating}

Samples were milled to $<5 \mathrm{~mm}$ and prepared to $\alpha$-cellulose using standard procedures (Hoper et al. 1998). All samples with the ANUA laboratory code were step-combusted at 330,650 , and $850{ }^{\circ} \mathrm{C}$ in a vacuum line insulated from atmospheric contamination by a secondary backing vacuum (Bird et al. 1999; Turney et al. 2001; Santos et al. 2001) housed at the University of Wollongong. Graphite targets were produced from the $\mathrm{CO}_{2}$ at the highest temperature step by catalytic reduction on iron powder (Merck; $10 \mu \mathrm{m}$ ) in an excess of $\mathrm{H}_{2}$ gas. ${ }^{14} \mathrm{C}$ ages were determined by AMS using the 14UंD accelerator at the Australian National University. Samples with the Wk laboratory code were converted to benzene and measured by LSC at the University of Waikato using the method described by Hogg et al. (these proceedings).

In addition to subfossil woods of unknown age, samples of known "infinitely" old material were also processed (Hogg et al., these proceedings). Hogg (2004) introduced the totara (Podocarpus totara) 110-kyr Airedale Reef Ancient Wood standard (ARAWI) obtained from a coastal section in North Taranaki, New Zealand. In addition to this, 2 new standards were also obtained: 1) a second Airedale Reef standard (ARAWII) composed of totara logs obtained from an intertidal marine platform stratigraphically below the ARAWI standard and dated by associated volcanic deposits to about 125 kyr (Newnham and Alloway 2001); and 2) kauri logs contained within an OIS-7 (>140 kyr; Marra et al. 2006) intertidal platform in Manukau Harbor, near Auckland airport, New Zealand. Using a statistical model developed by Galbraith (2005) to allow for variability in contamination beyond counting statistics, a mean background of $0.096 \pm 0.007$ pMC has been obtained for the AMS measurements (Hogg et al. 2006). We believe that the stepped combustion procedure is crucial to achieving such low backgrounds on cleaned $\alpha$-cellulose samples and hence in permitting a high degree of confidence in the final ages from the highest temperature fraction; previous results indicate that significant contamination is removed at the $330^{\circ} \mathrm{C}$ combustion step (Bird et al. 1999; Turney et al. 2001; Santos et al. 2001; cf. McNichol et al. 2006). 


\section{RESULTS}

\section{Prospects for a Continuous Record}

In all the sites investigated for OIS-3 samples, the wood is excellently preserved with no obvious indication that the material is of considerable antiquity. When excavated, the wood typically has bark still attached, with numerous macrofossils (such as cones) still found in association with the trees. In some instances, leaves will appear green when first excavated, turning brown under aerobic conditions.

Results for trees of previously unknown age are presented in Tables 1 and 2. Table 1 consists of "rangefinder" ages, where a single sample has been dated to determine where that particular tree sits in the OIS-3 timescale. Samples typically consisted of 10 to 20 rings obtained from the outer portion of the section. For the Awanui staircase tree, an additional 10-ring sample was taken from near the center of the tree. In contrast, Table 2 presents a series of measurements of 20-ring samples at 100year intervals across Specimen 9 from Trig Road - an individual tree that lived for $1050 \mathrm{yr}$.

A total of 16 subfossil (pre-Holocene) kauri sites have been identified, and rangefinder ${ }^{14} \mathrm{C}$ ages have been obtained from many of these. Of these sites, 7 have returned finite ${ }^{14} \mathrm{C}$ ages from $\alpha$-cellulose samples spanning the full range of OIS-3 (Table 1 and Figure 3). Ages of 24.9, 27.8 (Wk-16713 and -16711), and 28.5 kyr BP (Wk-17551) obtained from Finlayson Farm and Omaha Flats, respectively (Table 1), indicate that stands of kauri are preserved at the end of OIS-3 and the transition into OIS2. In contrast, material obtained from sites such as Duder Farm and Mangwhai Heads have ages of 60.4 kyr BP (Wk-15590-92, 15670-74, 15730-33) and 57.4 kyr BP (ANUA-33015), respectively, while the inner and outer samples of the Awanui "staircase" tree (ANUA-29029 and -29020) are statistically indistinguishable from one another and background ( $>56 \mathrm{kyr} \mathrm{BP}$ ), demonstrating that trees are available towards and beyond the limits of ${ }^{14} \mathrm{C}$ dating. In between these extremes, we have identified numerous trees (Figure 3), suggesting material is preserved throughout OIS-3.

Importantly, trees from several sites contain material representing populations that grew at different times through OIS-3. For instance, in addition to finite aged samples, wood from Duder Farm (ANUA-33017) and Omaha Flats (Wk-17550) has been found to be beyond the limits of ${ }^{14} \mathrm{C}$ dating. These results indicate that different trees from the same site can span a number of periods; thus, a single site does not necessarily contain one cohort of trees of approximately equal age. One measurement on an individual does not always capture the full potential of a site, and ideally rangefinder ages should be obtained from all suitably large trees (resources permitting).

At present, only a few intersite dendrochronology cross-matches for OIS-3 kauri have been successfully accomplished (Palmer et al. 2006). It was recognized early on in swamp kauri research that both tree-ring chronology construction and intersite cross-matching of subfossil kauri may be limited because of the low number of samples typically collected from most sites (Bridge and Ogden 1986). Of importance, where high sample numbers ( $>20)$ for OIS-3 kauri site chronologies have been achieved, inter- and intrasite cross-matching has been successful (Lorrey and Ogden 2005; Palmer et al. 2006), providing the possibility of developing a continuous record for calibration and paleoclimate studies. The relatively rich abundance of infinitely old wood suggests a dendrochronological scheme can be developed beyond the range of ${ }^{14} \mathrm{C}$ over the long term. Overall, there appears to be considerable scope that subfossil kauri can be obtained throughout OIS-3 (Table 1 and Figure 3 ), providing a critical contribution to a ${ }^{14} \mathrm{C}$ calibration curve spanning all of the timescale. 
Table $1{ }^{14} \mathrm{C}$ ages obtained from subfossil (oxygen isotope stage 3) Agathis australis, Northland, New Zealand. All samples were prepared to $\alpha$-cellulose. Asterisks $\left(^{*}\right)$ denote series of samples undertaken on the same Vinac Farm log using both LSC and AMS (Hogg et al., these proceedings).

\begin{tabular}{|c|c|c|c|}
\hline Sample & $\begin{array}{l}\text { Latitude (S), } \\
\text { Longitude (E) }\end{array}$ & Laboratory nr & ${ }^{14} \mathrm{C}$ age $\pm 1 \sigma$ \\
\hline $\begin{array}{l}\text { Awanui "Staircase" Tree } \\
\text { (Stewart Sawmill) }\end{array}$ & $35^{\circ} 02^{\prime}, 173^{\circ} 15^{\prime}$ & & \\
\hline Rings 10-20 (“inner”) & & ANUA-29029 & $>56,000$ \\
\hline Rings 1010-1020 (“outer”) & & ANUA-29020 & $>56,000$ \\
\hline Bibby Farm & $35^{\circ} 42^{\prime}, 173^{\circ} 32^{\prime}$ & $\begin{array}{l}\text { Wk-5383 } \\
\text { Wk-5385 }\end{array}$ & $\begin{array}{l}>50,000 \\
>50,000\end{array}$ \\
\hline Duder Farm & $35^{\circ} 42^{\prime}, 173^{\circ} 32^{\prime}$ & $\begin{array}{l}\text { ANUA-33016 } \\
\text { ANUA-33017 } \\
\text { Wk-15590-92, 15670-74, } \\
15730-33\end{array}$ & $\begin{array}{l}43,750+720-660 \\
>56,000 \\
60,400 \pm 630\end{array}$ \\
\hline Finlayson Farm & $35^{\circ} 50^{\prime}, 173^{\circ} 39^{\prime}$ & $\begin{array}{l}\text { Wk-16713 } \\
\text { Wk-16711 } \\
\text { Wk-7077 } \\
\text { Wk-16709 } \\
\text { Wk-16710 } \\
\text { Wk-16712 }\end{array}$ & $\begin{array}{l}24,940 \pm 170 \\
27,800 \pm 180 \\
30,340 \pm 360 \\
33,870 \pm 375 \\
44,670 \pm 1320 \\
46,140 \pm 1400\end{array}$ \\
\hline Lake Ngatu & $35^{\circ} 02^{\prime}, 173^{\circ} 11^{\prime}$ & Wk-16689 & $>55,270$ \\
\hline Mangawhai Heads & $36^{\circ} 08^{\prime}, 174^{\circ} 36^{\prime}$ & $\begin{array}{l}\text { Wk-15840 } \\
\text { ANUA-33015 } \\
\text { ANUA-33029 }\end{array}$ & $\begin{array}{l}38,470 \pm 880 \\
57,350+2550-1920 \\
51,450+3100-2250\end{array}$ \\
\hline Omaha Flats & $36^{\circ} 18^{\prime}, 174^{\circ} 30^{\prime}$ & $\begin{array}{l}\text { Wk-17551 } \\
\text { Wk-16955 } \\
\text { Wk-17550 } \\
\text { Wk-15838 }\end{array}$ & $\begin{array}{c}28,520 \pm 220 \\
32,840 \pm 135 \\
>47,330 \\
50,330 \pm 1110\end{array}$ \\
\hline Randall Farm & $36^{\circ} 06^{\prime}, 173^{\circ} 56^{\prime}$ & Wk-17809 & $>50,860$ \\
\hline Roe Farm & $35^{\circ} 48^{\prime}, 173^{\circ} 38^{\prime}$ & ANUA-33024 & $>56,000$ \\
\hline Stewart Sawmill & $35^{\circ} 02^{\prime}, 173^{\circ} 15^{\prime}$ & $\begin{array}{l}\text { Wk-7074 } \\
\text { Wk-7075 }\end{array}$ & $\begin{array}{l}>53,200 \\
>50,000\end{array}$ \\
\hline Sweetwater Farm & $35^{\circ} 04^{\prime}, 173^{\circ} 11^{\prime}$ & Wk-16714 & $>54,610$ \\
\hline Vinac Farm & $34^{\circ} 59^{\prime}, 173^{\circ} 11^{\prime}$ & $\begin{array}{l}\text { Wk-14419 } \\
\text { Wk-14427* } \\
\text { ANUA-29023, 29023, 31308, } \\
\text { 31309, 27104-27114* } \\
\text { ANUA-11710 } \\
\text { Wk-8163 }\end{array}$ & $\begin{array}{l}61,600 \pm 810 \\
59,400 \pm 1100 \\
48,710+1820-1480 \\
51,370+3240-2300\end{array}$ \\
\hline
\end{tabular}

Table 2 pMC values obtained from $\alpha$-cellulose and step-combusted samples from a subfossil Agathis australis log from Trig Road (Specimen 9), Northland, New Zealand.

\begin{tabular}{cclll}
\hline Trig Road & Ring $\mathrm{nr}$ & Laboratory $\mathrm{nr}$ & $\delta^{13} \mathrm{C}(\%)$ & $\mathrm{pMC} \pm 1 \sigma$ \\
\hline 1 & $40-59$ & ANUA-31220 & -22.4 & $0.143 \pm 0.017$ \\
2 & $140-159$ & ANUA-31310 & -22.3 & $0.183 \pm 0.033$ \\
3 & $240-259$ & ANUA-31311 & -22.8 & $0.110 \pm 0.028$ \\
4 & $440-459$ & ANUA-31314 & -22.1 & $0.160 \pm 0.028$ \\
5 & $540-559$ & ANUA-31221 & -22.7 & $0.121 \pm 0.018$ \\
6 & $640-659$ & ANUA-31316 & -23.2 & $0.166 \pm 0.024$ \\
7 & $740-759$ & ANUA-31223 & -22.1 & $0.122 \pm 0.022$ \\
8 & $840-859$ & ANUA-31317 & -21.5 & $0.173 \pm 0.046$ \\
9 & $940-959$ & ANUA-31318 & -21.4 & $0.190 \pm 0.030$ \\
10 & $1040-1059$ & ANUA-31224 & -21.3 & $0.103 \pm 0.018$ \\
\hline
\end{tabular}




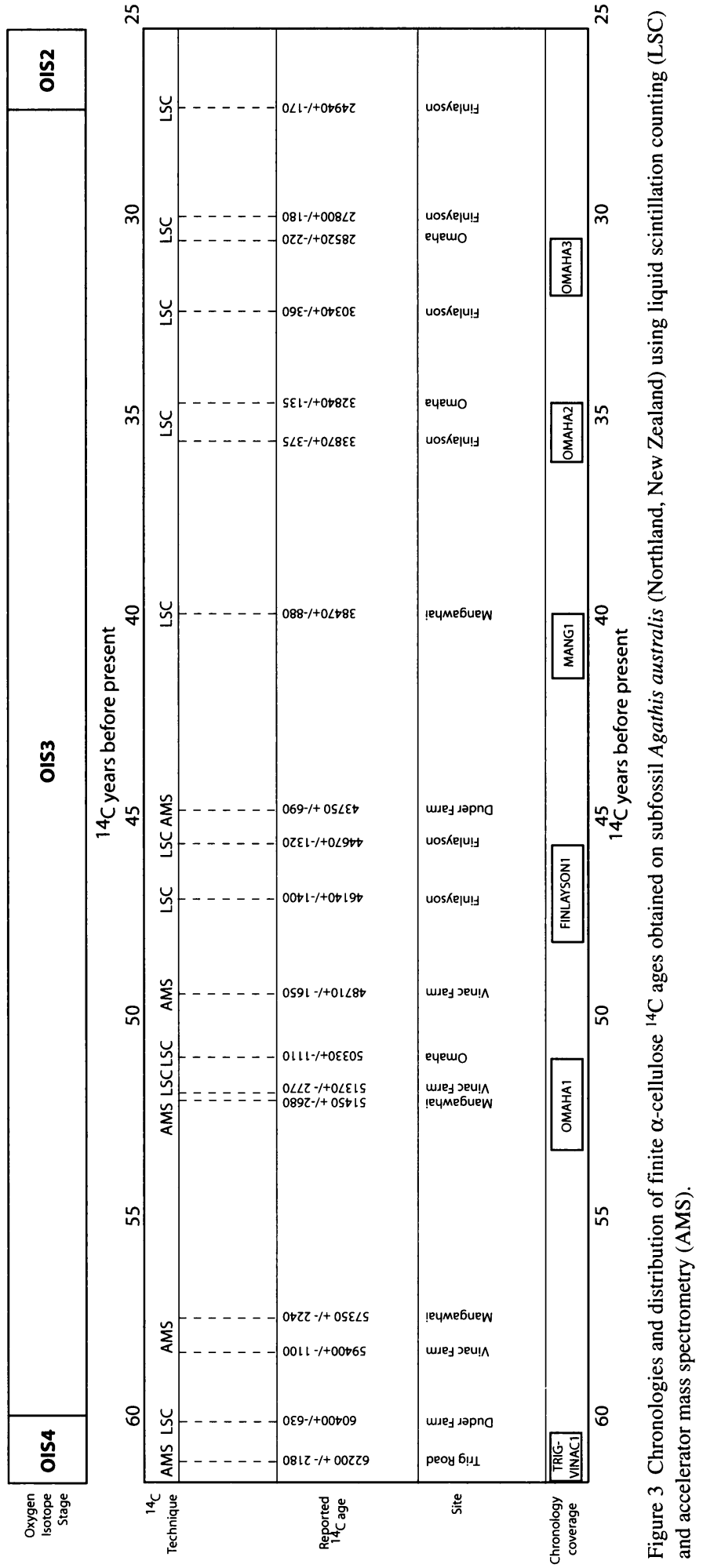




\section{Comprehensive Dating of a Single Tree}

A single tree (Specimen 9) was obtained from Trig Road; this individual has 1050 rings but a diameter of only $1.65 \mathrm{~m}$ and an average radial growth rate of $0.64 \mathrm{~mm} / \mathrm{yr}$. The average modern growth rate of kauri based on a sample of over 240 trees is $1.66 \mathrm{~mm} / \mathrm{yr}$ (Palmer et al. 2006). Other subfossil logs from OIS-3 typically had slower growth rates than modern trees (i.e. only $1.25 \mathrm{~mm} / \mathrm{yr}$ ). Specimen 9 is therefore exceptionally slow growing, even for OIS-3, and support that this was climatically induced is provided by macrofossil associations in the Trig Road sequence (Ogden et al. 1993). The ring widths have been plotted in Figure 4 and show some obvious extended periods of suppression and release. Another noticeable feature is the strong year-to-year variation or "sensitivity" (Fritts 1976) in the ring-width series; this is normally interpreted as providing a good indication that the tree is responding to environmental influences such as climate.

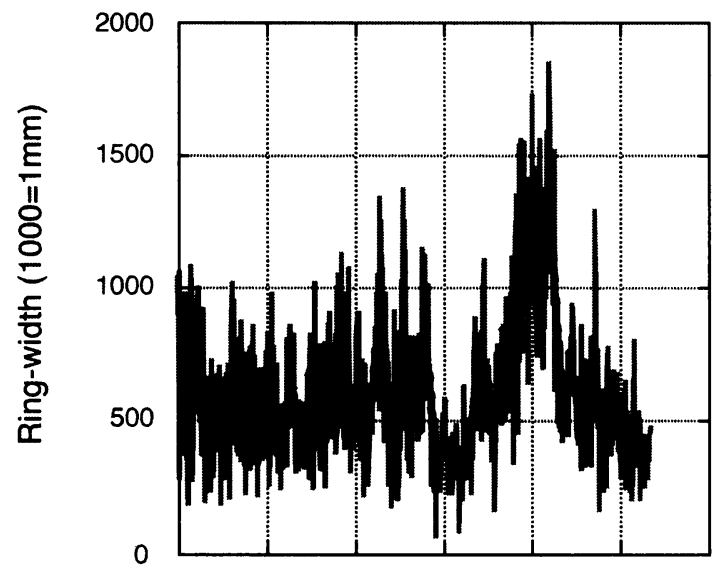

Figure 4 Ring-width and percentage modern carbon (pMC) values obtained on an individual kauri tree (Specimen 9) from Trig Road, Northland, New Zealand. The thin, gray bar denotes the mean background value of $0.096 \pm 0.007$ pMC obtained for AMS measurements using $\alpha$-cellulose extraction and stepped combustion on "infinitely" old material.

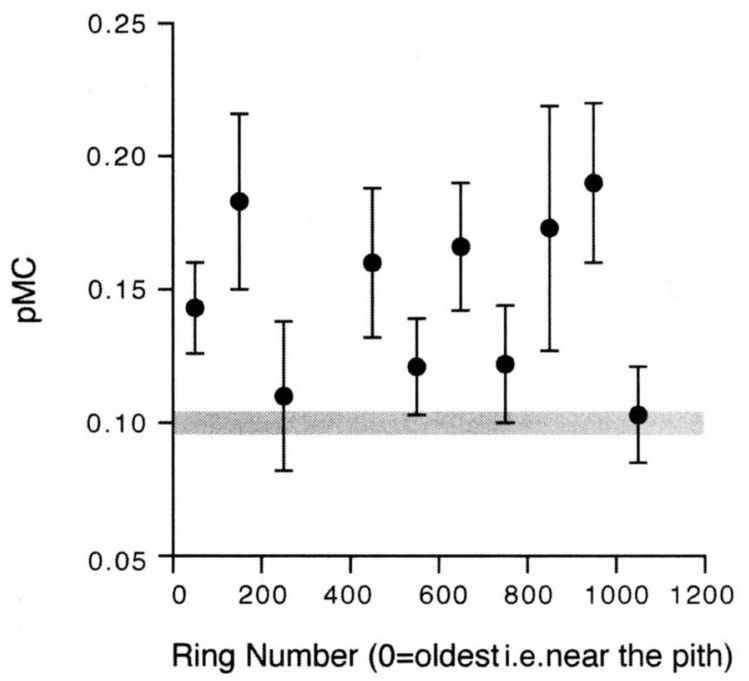

Bidecadal-block samples were taken at 100 -ring intervals. The 10 samples measured are reported in Table 2 and depicted graphically in Figure 4 . The tree had previously been dated close to background and was chosen here to assess the robustness of the method. The $\alpha$-cellulose extraction and stepped-combustion methodology was applied to the series of samples to ascertain whether repeat- 
able measurements could be made close (or beyond) the limit of the ${ }^{14} \mathrm{C}$ method. The pMC measurements provide a weighted mean value of $0.138 \pm 0.009 \mathrm{pMC}$. In deriving this mean value and its associated uncertainty, the prescription of Galbraith (2005) was employed to allow for sample-tosample variability over and above counting statistics, such as differences due to variations in contamination. The value obtained is statistically distinguishable from the background level of $0.096 \pm$ $0.007 \mathrm{pMC}$ at $2 \sigma$, although the mean ${ }^{14} \mathrm{C}$ age of $62,200+2470-1880$ is clearly at the upper limits of the ${ }^{14} \mathrm{C}$ method. Critically, however, these measurements demonstrate that reproducible ${ }^{14} \mathrm{C}$ ages can be determined back to at least $60 \mathrm{kyr} \mathrm{BP}$ (Table 2 and Figure 4), traditionally considered beyond the dating capability of the method. Although these results in themselves do not constitute a "floating radiocarbon calibration curve," they do demonstrate the effectiveness of $\alpha$-cellulose and stepped combustion on subfossil wood. Work is currently being undertaken on cross-dated kauri samples within OIS-3, allowing us to test hypotheses of ${ }^{14} \mathrm{C}$ excursions during this crucial period (Beck et al. 2001), and in the long term develop a continuous calibration data set.

\section{CONCLUSIONS}

The determination of a reliable calibrated timescale encompassing the full range of the ${ }^{14} \mathrm{C}$ dating method is crucial if we are to fully understand the mechanisms of climatic, environmental, and archaeological change through the last glacial period. Unfortunately, however, there is no internationally accepted ${ }^{14} \mathrm{C}$ calibration curve beyond $26 \mathrm{kyr}$ cal BP, largely due to inherent problems with the materials used. Ideally, dendrochronologically dated subfossil trees can provide annuallyresolved samples on an absolute timescale, with the additional assurance that their carbon content is truly representative of atmospheric $\mathrm{CO}_{2}$ at the time of growth. The principal sources of uncertainty that have plagued other attempts at calibration in this time range are thereby avoided. Here, we show the considerable potential of New Zealand kauri (Agathis australis) for developing a ${ }^{14} \mathrm{C}$ calibration back to $60 \mathrm{kyr}$ BP. Extensive work is now underway to cross-date and measure the ${ }^{14} \mathrm{C}$ content of subfossil kauri in order to establish the calibration curve over this crucial period.

\section{ACKNOWLEDGMENTS}

Our many thanks to Dave Stewart (Ancient Kauri Kingdom, Awanui) for providing material in this work and Stephen Hoper at the Queen's University Radiocarbon Laboratory. Richard Miller (University of Wollongong) kindly drew Figure 1. This work was funded by the UK National Environment Research Council Grant (NER/A/S/2001/01037), the Australian Research Council (DP0451152), and a New Zealand Marsden Award (UOW-302). Chris Turney holds an ARC Queen Elizabeth II Fellowship.

\section{REFERENCES}

Baillie MGL. 1982. Tree-Ring Dating and Archaeology. London: Croom-Helm. 274 p.

Beck JW, Richards DA, Edwards RL, Silverman BW, Smart PL, Donahue DJ, Hererra-Osterheld S, Burr GS, Calsoyas L, Jull AJT, Biddulph D. 2001. Extremely large variations of atmospheric ${ }^{14} \mathrm{C}$ concentration during the last glacial period. Science 292(5526): 2453-8.

Bird MI, Ayliffe LK, Fifield LK, Turney CSM, Cresswell RG, Barrows TT, David B. 1999. Radiocarbon dating of "old" charcoal using a wet oxidation, stepped-combustion procedure. Radiocarbon 41(1):127-40.

Boswijk G, Fowler A, Lorrey A, Palmer J, Ogden J. 2006.
Extension of the New Zealand kauri (Agathis australis) chronology to $1724 \mathrm{BC}$. The Holocene 16(2):18899.

Bridge MC, Ogden J. 1986. A sub-fossil kauri (Agathis australis) tree-ring chronology. Journal of the Royal Society of New Zealand 16:17-23.

Buckley B, Ogden J, Palmer J, Fowler A, Salinger J. 2000. Dendroclimatic interpretation of tree-rings in Agathis australis (kauri). 1. Climate correlation functions and master chronology. Journal of the Royal Society of New Zealand 30(3):263-75.

Cranwell LM. 1939. Native vegetation. D.S.I.R. [Department of Scientific and Industrial Research] Bulletin 
(Wellington, New Zealand) 76:23-30.

Fairbanks RG, Mortlock RA, Chiu T-C, Cao L, Kaplan A, Guilderson TP, Fairbanks TW, Bloom AL, Grootes PM, Nadeau M-J. 2005. Radiocarbon calibration curve spanning 0 to 50,000 years BP based on paired ${ }^{230} \mathrm{Th} /{ }^{234} \mathrm{U} /{ }^{238} \mathrm{U}$ and ${ }^{14} \mathrm{C}$ dates on pristine corals. Quaternary Science Reviews 24(16-17): 1781-96.

Fowler A, Palmer J, Salinger J, Ogden J. 2000. Dendroclimatic interpretation of tree-rings in Agathis australis (kauri). 2. Evidence of a significant relationship with ENSO. Journal of the Royal Society of New Zealand 30(3):277-92.

Friedrich M, Remmele S, Kromer B, Hofmann J, Spurk M, Kaiser KF, Orcel C, Küppers M. 2004. The 12,460year Hohenheim oak and pine tree-ring chronology from central Europe-a unique annual record for radiocarbon calibration and paleoenvironment reconstructions. Radiocarbon 46(3):1111-22.

Fritts HC. 1976. Tree Rings and Climate. New York: Academic Press. 579 p.

Galbraith R. 2005. Statistics for Fission Track Analysis. Boca Raton, Florida, USA: Chapman \& Hall / CRC. $240 \mathrm{p}$.

Hogg AG. 2004. Towards achieving low background levels in routine dating by liquid scintillation spectrometry. Radiocarbon 46(1):123-31.

Hogg AG, Fifield LK, Palmer JG, Turney CSM, Galbraith R, Roberston S. 2007. Robust radiocarbon dating of wood samples by high sensitivity liquid scintillation spectroscopy in the 50-70 kyr age range. Radiocarbon, these proceedings.

Hogg AG, Fifield LK, Turney CSM, Palmer JG, Galbraith R, Baillie MGL. 2006. Dating ancient wood by highsensitivity liquid scintillation counting and accelerator mass spectrometry - pushing the boundaries. Quaternary Geochronology 1(4):241-8.

Hoper ST, McCormac FG, Hogg AG, Higham TFG, Head MJ. 1998. Evaluation of wood pretreatments on oak and cedar. Radiocarbon 40(1):45-50.

Hughen K, Lehman S, Southon J, Overpeck J, Marchal O, Herring C, Turnbull J. 2004. ${ }^{14} \mathrm{C}$ activity and global carbon cycle changes over the past 50,000 years. Science 303(5655):202-7.

Kitagawa H, van der Plicht J. 1998. Atmospheric radiocarbon calibration to 45,000 yr B.P.: Late Glacial fluctuations and cosmogenic isotopic production. Science 279(5354):1187-90.

Kitagawa H, van der Plicht J. 2000. Atmospheric radiocarbon calibration beyond 11,900 cal BP from Lake Suigetsu laminated sediments. Radiocarbon 42(3): 369-80.

Lorrey AM, Ogden J. 2005. Tree-ring analysis of subfossil kauri (Agathis australis) from Omaha Flats, Tawharunui Peninsula, New Zealand. New Zealand Tree-ring Site Report 22 School of Geography and Environmental Science Working paper 32. ISSN: 11758465; ISBN: 1-8777320-18-8.
Marra MJ, Alloway BV, Newnham RM. 2006. Paleoenvironmental reconstruction of a well-preserved Stage 7 forest sequence catastrophically buried by basaltic eruptive deposits, northern New Zealand. Quaternary Science Reviews 25(17-18):2143-61.

McNichol AP, Gerlach DS, Rosenheim BE, Edgerton ES, Hayes JM. 2006. Measuring the radiocarbon content of labile and refractory carbon in the same sample to constrain the natural carbon cycle [talk presented at the 19th International Radiocarbon Conference]. 3-7 April 2006, Oxford University.

Newnham RM, Alloway BV. 2001. The last interglacial/ glacial cycle in Taranaki, western North Island, New Zealand: a palynostratigraphic model. In: Goodman DK, Clarke RT, editors. Proceedings of the IX International Palynological Congress. Houston 1996. Dallas: American Association of Stratigraphic Palynologists Foundation. p 411-22.

Ogden J, Newnham RM, Palmer JG, Serra RG, Mitchell ND. 1993. Climatic implications of macro- and microfossil assemblages from late Pleistocene deposits in northern New Zealand. Quaternary Research 39(1): 107-19.

Ogden J, Wilson A, Hendy C, Newnham RM, Hogg A. 1992. The late Quaternary history of kauri (Agathis australis) in New Zealand and its climatic significance. Journal of Biogeography 19(6):611-22.

Palmer J, Lorrey A, Turney CSM, Hogg A, Baillie M, Fifield K, Ogden J. 2006. Extension of New Zealand kauri (Agathis australis) tree-ring chronologies into oxygen isotope stage (IOS) 3. Journal of Quaternary Science 21(7):779-87.

Reimer PJ, Baillie MGL, Bard E, Bayliss A, Beck JW, Bertrand CJH, Blackwell PG, Buck CE, Burr GS, Cutler KB, Damon PE, Edwards RL, Fairbanks RG, Friedrich M, Guilderson TP, Hogg AG, Hughen KA, Kromer B, McCormac G, Manning S, Bronk Ramsey C, Reimer RW, Remmele S, Southon JR, Stuiver M, Talamo S, Taylor FW, van der Plicht J, Weyhenmeyer CE. 2004. IntCal04 terrestrial radiocarbon age calibration, 0-26 cal kyr BP. Radiocarbon 46(3): 1029-58.

Roig FA, Le-Quesne C, Boninsegna JA, Briffa KR, Lara A, Grudd H, Jones PD, Villagrán C. 2001. Climate variability 50,000 years ago in mid-latitude Chile as reconstructed from tree rings. Nature 410(6828):56770.

Santos GM, Bird MI, Pillans B, Fifield LK, Alloway BV, Chappell J, Hausladen PA, Arneth A. 2001. Radiocarbon dating of wood using different pretreatment procedures: application to the chronology of Rotoehu Ash, New Zealand. Radiocarbon 43(2A):239-48.

Stokes MA, Smiley TL. 1968. An Introduction to TreeRing Dating. Chicago: University of Chicago Press. $73 \mathrm{p}$.

Turney CSM, Bird MI, Fifield LK, Roberts RG, Smith M, Dortch CE, Grün R, Lawson E, Ayliffe LK, Miller GH, Dortch J, Cresswell RG. 2001. Early human oc- 
cupation at Devil's Lair, southwestern Australia 50,000 years ago. Quaternary Research 55(1):3-13.

Turney CSM, Roberts RG, Jacobs Z. 2006. Progress and pitfalls in radiocarbon dating. Nature 443: E3. doi: 10.1038 /nature05214.

van der Plicht J, Beck JW, Bard E, Baillie MGL, Blackwell PG, Buck CE, Friedrich M, Guilderson TP, Hughen KA, Kromer B, McCormac FG, Bronk Ramsey C, Reimer PJ, Reimer RW, Remmele S, Richards DA, Southon JR, Stuiver M, Weyhenmeyer CE. 2004.
NotCal04-comparison/calibration ${ }^{14} \mathrm{C}$ records $26-50$ kyr BP. Radiocarbon 46(3):1225-38.

Voelker AHL, Grootes PM, Nadeau M-J, Sarnthein M. 2000. Radiocarbon levels in the Iceland Sea from 25$53 \mathrm{kyr}$ and their link to the Earth's magnetic field intensity. Radiocarbon 42(3):437-52.

Yokoyama Y, Esat TM, Lambeck K, Fifield LK. 2000. Last ice age millennial scale climate changes recorded in Huon Peninsula corals. Radiocarbon 42(3):383401 . 